\title{
Post-Editing as the Means to Activate Students' Thinking and Analytical Process: Psycholinguistic Aspects
}

\section{Пост-редагування машинного перекладу як засі6 активізації мисленнєво-аналітичної діяльності студентів: психолінгвістичний аспект}

\section{Leonid Chernovaty}

Dr. Sc. in Pedagogy, Full Professor

\section{Леонід Черноватий}

доктор педагогічних наук, професор

E-mail: leonid.m.chernovaty@meta.ua

http://orcid.org/0000-0003-3411-9408

Natalia Kovalchuk

Ph.D. in Pedagogy,

Associate Professor
Наталя Ковальчук

кандидат педагогічних наук, доцент

E-mail: kovalnatalya@bigmir.net

http://orcid.org/0000-0002-9483-4297

V.N. Karazin Kharkiv National University (Ukraine)

4, Svoboda Square, Kharkiv, Ukraine, 61022
Харківський начіональний університет імені В.Н. Каразіна

(Україна)

майдан Свободи, 4, Харків, Україна, 61022

Original manuscript received January 18, 2021

Revised manuscript accepted September 29, 2021

\section{ABSTRACT}

The aim of the research is looking for the ways to intensify the future translators' analytical and thinking activity during their independent work in online teaching. The author strives to achieve it through the combination of post-editing machine-translated texts and the Think-aloud protocol procedure. It is also assumed that this combination 
reduces the students' dependence on the MT target text structure, as well as improves their competence in translating specialized texts.

The methodology of research involved experimental post-editing-based online teaching (28 contact hours and 92 hours of independent work) of an elective university course 'Specifics of translating English-language discourse in the domain of Psychology' to the first-year MA students (majoring in English and Translation) whose command of English ranged from C1 to C2 levels in the CEFR classification. The parameters of analysis included the percentage of the students' uploaded home tasks, the degree of the subjects' post-editing intensity in their weekly homework, the students' independence in the interim and final tests, as well as the marks in the Final test.

The results of the analysis demonstrated a substantial difference between various groups of the subjects by all indicators. The amount of home tasks uploaded by the subjects in groups $A$ and $B$ (with more intensive analytical and thinking activity) exceeds the similar parameter in groups $C$ and $D$ (with less intensive activity) more than twofold. There is a considerable advantage of the groups $A$ and $B$ (and even $C$ ) subjects' post-editing intensity in their weekly homework as compared to group $D$. The intensity of the students' analytical and thinking activity decreased from the highest (group A) to moderately high (group B) to average (group C) and to low (group D). The degree of the students' independence in the interim and final tests decreased from $85.0 \%$ (group $A$ ) to $35.0 \%$ in group $D$, with the remaining groups' indicators in between - 59.0\% (group B) and $46.0 \%$ (group C). These indicators clearly correlate with the average marks in the final test, which amounted to 93.80, 63 and 53 points (out of 100) in groups $A, B, C$ and $D$ respectively.

Conclusions. Post-editing, in combination with the modified TAP procedure, contributes to the efficient development of the specialized texts translation competence due to the intensification of the students' analytical and thinking activity, reduces their dependence on the MT target text structure and correlates with the improvement of the overall quality of their translation.

Key words: analytical and thinking activity, machine translation, online teaching, postediting, Psychology, specialized translation, TAP procedure, translation.

\section{Introduction}

Before the actual presentation of our research, it seems reasonable to define some of the terms used in this paper to avoid their misinterpretation. They include: human translation - the one done by a human being; trans-human translation - the one that goes beyond the purely human translation and additionally involves automated translation systems, such as machine translation (MT), computer aided translation (CAT) tools, translation memory (TM), etc.; pre-editing - removing from the source text (ST) specific linguistic features (or negative 
translatability indicators (Underwood \& Jongejun, 2001) that may be problematic for MT systems (Mellinger, 2018); post-editing - may range from editing only the MT target text (TT) to a complete comparison of the ST and TT with revisions made for style, terminology, or logic (Mellinger, 2018); editing (review) - involves only the TT and is not checking the TT against the ST (ISO 171000, 2015; Mellinger, 2018); revision - constitutes a check of the TT against the ST (ISO 171000, 2015; Mellinger, 2018); Think-aloud Protocol (TAP) - a data-gathering method where the subjects verbalise their thought process (CifuentesFerez \& Rojo 2015).

The research into the impact of information and communication technologies (ICT) upon the psychological processes in the students' minds in translator and interpreter training and teaching, and consequently - on the efficiency of the latter, has been in the focus of many authors' attention and the subject of numerous publications.

Specifically, a large-scale survey of 438 validated respondents, including freelance translators, language service providers, translator trainers, and academics (Gaspari et al., 2015), proved the ever increasing importance of ICT, including MT, assessment techniques and postediting in the translation and localisation industry. A similar survey of translation technology adoption (Man et al., 2020) among 441 Chinese students enrolled on a MA Programme in Translation and Interpreting demonstrated a strong, positive correlation between students' knowledge and their use of translation technology. Other authors (Kenny \& Doherty, 2014; Rodríguez de Céspedes, 2019) also support the idea of designing and implementing a new translator-oriented MT syllabus, arguing for a holistic approach to the integration of MT into translator training programmes, one that empowers rather than marginalises translators.

The comparative efficiency of human and post-edited MT remains a contested issue. Some authors (Loock, 2018), basing on their original research, argue for an unconditional advantage of human over machine translation. Other researchers (Daems et al., 2017), also basing on the original experiments, came to the conclusion that both methods are more similar than anticipated. Still others (Yang et al., 2021) report that MT post-editing is more efficient than human translation while the research into the Korean undergraduate students' post-editing the output of Google Translate (medical texts) (Sang-Bin, 2018) found the procedure to be inefficient. The students, among other things, inadequately 
performed pre- and post-editing, used dictionaries too frequently and spent too much time on non-technical words. The author concludes that the priority should be given to improving students' basic translation competence rather than skills specific to post-editing.

There have been attempts to rethink the opposition of human translation vs ICT (including MT) translation (Alonso \& Calvo, 2015), suggesting the idea of trans-human translation that goes beyond the purely human translation and additionally involves automated translation systems. The authors believe the idea envisages a stimulating future for translators, where they will use technological extensions in a creative and critical way.

The arrival of next-generation MT software, including the one based on statistical and neural networks (Schmidhofer \& Mair, 2019; O’Brien \& Rossetti, 2020), made some authors (Pym, 2013) predict its eventual replacement of fully human translation in many spheres of activity. Thus, it is suggested (Pym, 2013; Mellinger, 2017) to incorporate MT in multiple courses across the curriculum (or, at least, the majority of translation-related disciplines), rather than concentrating the material in a stand-alone course or module, though there are some other opinions concerning this issue as well (Esqueda, 2021).

On the other hand, the research (Moorkens, 2018) into comparative efficiency of neural (NMT) and statistical machine translation (SMT) systems in several language pairs proved that the euphoria concerning the new MT engines is slightly premature.

In general, though most of the authors agree that MT is one of the most innovative technologies in the field of translation, many of them have shown certain restraint, arguing that it is still too early to predict how it can support the creativity and productivity of professional translators in the future (Burchardt et al., 2016).

The problem of MT application in the future translator training and teaching has gone complicated after this process went completely online because of the COVID restrictions. As all home tasks (at least those to be done in writing) within this specialization involve translation, and each student can immediately translate any text by just touching a button, there emerge serious concerns about the possibility of developing a full-fledged translator competence under such conditions. During this momentary operation, the student's mind remains passive, as it is not engaged either in the ST processing, translation problems 
identification and the related decision making concerning many levels (semantic, lexical, grammatical, stylistic, logical, etc.) involved, or the TT generation. The said touch on the button does not contribute to developing a corresponding neural network that provides for the translation process in the student's mind. Thus, the translator competence development just does not occur. The teacher's calls for the MT-free homework are generally ineffective because the temptation to save time for most of the students is too strong to resist. It has been proven experimentally as well: one research (Yang et al., 2021) found that the students perceive the amount of time and work that is saved when using MT to be a greater benefit than the overall utility of MT. The expectations that students compensate the said loss in the amount of analytical and thinking activity by post-editing the MT TT rarely come true. Most students tend to limit their operations to the mere replacement of several words in a sentence with their synonyms, if any.

The direct ban on the use of MT in home tasks is counterproductive either - the students easily avoid it, for example, by involving a third language. Say, the machine translates the ST from English into German and then - from German into Ukrainian. Teachers would find it more difficult to prove the MT manipulations in this case. Thus, the aim of our research was to develop a translator training system that could promote the students' analytical and thinking activity in the process of doing their home tasks in the hope that it would contribute to the efficient development of each student's translator competence. To achieve this aim, we had to accomplish several objectives: to define the principles of the said system; select the subjects and the domain the research would be related to; organize and conduct the experimental teaching and tests; represent, process and interpret the experimental data; formulate the preliminary conclusions; outline the prospect of further research.

The absence of the research into the ways of boosting the students' analytical and thinking activity and its impact on the efficiency of online instruction provides for the novelty of this study, because the said form of teaching has never been used on such a large scale.

\section{Methodology}

Our research was based on the following hypothesis: In online translation teaching, the regular post-editing of MT TT, in combination 
with the TAP procedure, promotes the students' analytical and thinking activity in their independent work. In its turn, the said activity contributes to the efficiency of specialized texts translation skills development. It is expected that, as a result, the students' dependence on the MT TT structure will be reduced, while the quality of their independent (without MT) translation will improve.

Because, as it was mentioned earlier, the ban on the MT use in the students' home tasks is not productive, within our approach, the MT application was not only allowed, but it was mandatory. That is, the students had to translate the ST from English into Ukrainian by means of the Google Translate system and post-edit the resulting MT TT. To promote the students' analytical and thinking activity in doing their home tasks, and avoid the formalistic approach to their post-editing (mere substitution of several words with their synonyms, etc.), we used a modified form of the Think-aloud protocol (TAP) (Cifuentes-Ferez \& Rojo, 2015) experimental procedure. In it, unlike the TAP classical form, where the subjects' reflections on the actions they perform are recorded and then analyzed, the students had to explain in writing, why they had edited the particular fragment of the MT TT (see the example below) - the fragments changed in the process of post-editing are shown in italics.

\begin{tabular}{lll}
\hline ST & МТ ТТ & Роst-еdited ТT \\
\hline It has been argued that due to & Було аргументовано, що & Вважається, що специфіка \\
the nature of the problem of & через природу проблеми & цієї проблеми робить \\
consciousness, empirical tests & свідомості емпіричні тести & застосування емпіричних \\
are intrinsically impossible. & по суті неможливі. & тестів при їі дослідженні \\
& & практично неможливим. \\
\hline
\end{tabular}

Concerning the post-editing of this sentence, the students' explanations could be as follows: In the first sentence, at the syntactic level, we see practically completely literal translation - the words in the MT TT almost exactly follow their order in the ST. Consequently, the MT TT looks unnatural and requires some rephrasing and word order changes. The literal translation prevails at the word and collocation levels as well (it has been argued - було аргументовано, nature of the problem of consciousness - природа проблеми свідомості, empirical tests are intrinsically impossible - емпіричні тести по суті неможливі). Thus, at the post-editing stage, the target text collocations 
were modified by means of contextual substitution (вважкасться, специфіка цісї проблеми, робить застосування емпіричних тестів... практично неможливим) to meet the target language norms. Other changes in the post-edited text included word additions: "робить застосування" and "при ії дослідженні".

To test our hypothesis, we conducted a pilot experimental study within a semester-long elective course 'Specifics of translating English-language discourse in the domain of Psychology'. Its duration constituted 120 academic hours (28 contact hours and 92 hours for independent work). The course covered some basic topics of Psychology as a science (History of Psychology, Methods of Research, Cognitive Psychology, Consciousness, Intelligence, Attention, Perception, Thinking, Personality and Memory) and was based on the appropriately orientated original texts.

The subjects included 23 first-year (second semester) MA students majoring in Germanic languages and Literature (Translation included) (20 females and 3 males) of the School of Foreign Languages at V.N. Karazin Kharkiv National University (Ukraine), 21 to 24 years of age, who studied English as their first foreign language. By the beginning of the experiment, their total amount of contact hours for learning English at university exceeded 1500, without taking into account their related experience in the secondary school. Thus, within the CEFR classification (CEFR, 2018), the expected level of their command of English ranged from $\mathrm{C} 1$ to $\mathrm{C} 2$. Their experience in specialized translation (social-political, economic, legal, in the domains of technology and natural sciences) amounted to over 200 contact hours. The subjects were properly motivated as the results of their homework were taken into account when assessing their progress within the said course.

Because of the previously mentioned COVID restrictions, this course was conducted completely online. Once a week, the students had one online class ( 80 minutes) with a teacher, where a new topic material was introduced, and the students did some sight translation exercises concerning the texts the teacher displayed on the screen. Then the students were given their home task, which included some preparatory exercises, as well as the texts, which the students translated by means of MT and then post-edited in the above-mentioned manner. The results of their post-editing, complete with their explanation of the 
accompanying reasons for their corrections, had to be uploaded into a corresponding Google Classroom before the beginning of the next class.

To stimulate the students' work, we used a system that enabled each of them to be awarded 60 points for their semester activities (14 for attendance $(1 \times 14), 18$ - for home-tasks ( $1,5 \times 11$ plus 1,5 bonus for the upload of all home tasks), 6 - for online class presentations of their post-editing ( $3 \times 2), 22$ - for interim tests $(11 \times 2)$ and $40-$ for the final test.

The weekly home tasks uploaded by the students into their Google Classroom were analysed according to several indicators. This paper is limited to the investigation of only one of them - the degree of the students' post-editing intensity. As it was mentioned above, it is critical to prevent the students' formalistic approach to the post-editing activities and provide for their creativity in this process, thus contributing to the promotion of their analytical and thinking activity.

To establish the degree of the students' post-editing intensity, which, as we had assumed, had to contribute to the translation efficiency in general, we analysed each student's work according to a number of criteria (see further) and, following the results of the analysis, referred it to one of the four levels $(A-D)$ : A - completely independent post-editing, many corrections with motivated explanations; B - mostly independent post-editing, a moderate quantity of corrections, occasionally lacking motivated explanations; C - mostly formal post-editing, an insignificant amount of corrections, mostly lacking motivated explanations; D - completely formal post-editing, few corrections without motivated explanations, omission of obvious errors in the MT TT.

To fine-tune the process of the students' home tasks classification, we developed a special 10-point scale, where each of the four levels was assigned a numeric indicator (see Table 1).

\section{Table 1}

The assessment levels and their numeric indicators

\begin{tabular}{lllllllllll}
\hline Level & $\mathrm{A}$ & $\mathrm{A} / \mathrm{B}$ & $\mathrm{B} / \mathrm{A}$ & $\mathrm{B}$ & $\mathrm{B} / \mathrm{C}$ & $\mathrm{C} / \mathrm{B}$ & $\mathrm{C}$ & $\mathrm{C} / \mathrm{D}$ & $\mathrm{D} / \mathrm{C}$ & $\mathrm{D}$ \\
Numeric indicators & 10 & 9 & 8 & 7 & 6 & 5 & 4 & 3 & 2 & 1 \\
\hline
\end{tabular}

If, having checked the student's home task, the teacher decides that by the degree of the post-editing intensity (see the meaning of this 
indicator above) this particular work should be undoubtedly classified as belonging to level $\mathrm{A}, \mathrm{s} / \mathrm{he}$ gives it the mark of 10 . If the teacher hesitates between the levels of $\mathrm{A}$ and $\mathrm{B}$, and finally decides in favour of $A$, the mark is 9 , but if $s /$ he chose $B$, the mark is 8 . However, if the teacher does not have any doubts that it is level $\mathrm{B}$, the mark is 7 . The same procedure is applied if the student's work belongs to one of the lower levels $\mathrm{C}$ or $\mathrm{D}$, or their combinations.

To provide the data for the analysis and establish the hypothetical impact of students' analytical and thinking activity intensity in doing their homework upon the change of their attitude to post-editing, as well as on the expected improvement of their translation quality, we carried out two interim tests and a final one. Formally, within those tests, the students were not allowed to use MT engines under threat of cancellation, but there were no technical means to exclude this possibility, so the students' TTs were evaluated by comparing them with the MT TT. The interim tests were completed at the fourth and seventh class periods, while the final test - at the last one. During the said tests the students translated from English into Ukrainian the texts related to the topics they had covered in the preceding course segment (Interim test 1 - The cognitive model of mind, Interim test 2 - The relationship between the intelligence and attention, Final test - Psychological and neural conceptions of memory). The text size and the time allowed for translation amounted to 1369 characters and 40 minutes in Interim test 1, 2803 characters and 70 minutes in Interim test 2, and 2958 characters and 70 minutes in the Final test,

The interim and final tests were assessed by a number of indicators, from among which, in this paper, we analyse only the degree of the students' post-editing intensity in comparison with the overall accuracy of rendering the ST information in the TT. In the latter case, three types of errors and mistakes were differentiated with the corresponding amount of penalty points (p.p.) assigned for each of them: type 1 - language mistakes that do not prevent the comprehension of the ST content (0.1 p.p.); type 2 - ambiguity that (depending on the target readers' background and/or subject knowledge) might prevent the comprehension of the ST content (0.5 p.p.); type 3 - omission or distortion of the ST content that causes its misunderstanding on the part of the target reader (1.0 p.p.). The sum of each student's penalty points 
was then transformed into a conventional 100-point scale by means of a specially developed conversion scale.

\section{Adherence to Ethical Standards}

Before the actual experiment, we obtained informed consent from its potential participants to take part in the research. In the course of our empirical research, we observed the applicable ethical principles, specifically the principles of voluntary participation, informed consent and confidentiality. Because the experiment was a natural one, no funding was received to conduct this research. The authors do not have any financial or property interests concerning the materials presented in this article.

\section{Results and discussion}

In this section, we present our results concerning the degrees of the students' post-editing intensity in their weekly home tasks and their independence in the Interim and Final tests.

The data underlying this article are available in the international repository Social Science Research Network (Chernovaty, 2021).

Table 2 shows the results of the subjects' performance analysis within cycle 1 - home tasks (weeks 1-3) and the interim test 1 (due to technical problems, we excluded two subjects - N7 and N9 - from our analysis).

\section{Table 2}

The degrees of the students' post-editing intensity in their weekly home tasks 1-3 and their independence in the Interim test 1 (TN - task number, $\Sigma$ - sum total, IT - interim test, $(-)$ - the task was not uploaded by the student)

\begin{tabular}{|c|c|c|c|c|c|c|c|c|c|c|c|c|c|c|c|c|c|c|c|c|c|}
\hline \multirow{2}{*}{$\mathrm{TN}$} & \multicolumn{21}{|c|}{ Subjects } \\
\hline & 1 & 2 & 3 & 4 & 5 & 6 & 8 & 9 & 11 & 12 & 13 & 14 & 15 & 16 & 17 & 18 & 19 & 20 & 21 & 22 & 23 \\
\hline 1 & 9 & - & - & 9 & 6 & 5 & 9 & 9 & 1 & 9 & 2 & 9 & 9 & 7 & 10 & - & 3 & 7 & 10 & 8 & 8 \\
\hline 2 & 10 & - & - & 10 & 7 & - & 10 & 10 & - & 10 & 3 & 9 & 9 & 5 & 10 & - & 3 & 7 & 10 & 8 & 8 \\
\hline 3 & 10 & - & - & 10 & 7 & - & 10 & 10 & - & 10 & 2 & 9 & 10 & 4 & 8 & - & 3 & - & 10 & 8 & 8 \\
\hline$\Sigma$ & 29 & - & - & 29 & 20 & 5 & 29 & 29 & 1 & 29 & 7 & 27 & 28 & 16 & 28 & - & 9 & 14 & 30 & 24 & 24 \\
\hline IT-1 & 9 & - & 1 & 10 & 7 & 1 & 6 & 8 & 1 & 10 & 1 & 3 & 4 & 2 & 9 & 2 & 2 & 3 & 8 & 4 & 6 \\
\hline
\end{tabular}


As it follows from table 2, the assumption regarding the relationship between the subjects' post-editing intensity in their weekly home tasks and their independence in the Interim test 1 has been only partially corroborated. Specifically, it concerns subjects 1, 4, 9, 12, 17 and 21 , whose high home tasks sum total (28-30 points) correlates well with the similarly high results in the Interim test 1 (8-10 points).

The equally obvious negative correlation (that also corroborates our assumption) is clear concerning the subjects who did not do any home tasks at all (subjects 2, 3 and 18), did them formally (13 and $19)$ or partially and mostly formally $(6,11,20)$. The degree of their independence in the Interim test 1 was very low (1-3 points), i.e. they uploaded the non-edited MT TTs, or their changes were purely symbolic (addition or deletion of some of the words, synonyms substitution with corresponding grammar agreements without any essential changes in the sentence structure or its lexical composition). For example, the sentence Our thoughts can then serve as the basis of "outputs", such as language or physical behavior, which was translated by the computer as Тоді наші думки можуть слугувати основою "результатів", таких як мова чи фізична поведінка, was completely preserved by subject 3, who just substituted the first and the fifth words with their synonyms (the substitutions are shown in bold type): Таким чином, наші думки можуть бути основою 'результатів', таких як мова чи фізична поведінка.

On the other hand, the results of some subjects $(8,15$ and 22) in the Interim test 1 do not meet the expectations that followed from their home task indicators. The most striking difference was observed concerning subjects 8 and 15, who demonstrated very high results in their weekly home tasks (9-10 points in each of them) but performed relatively worse in the Interim test 1 (6 and 4 points correspondingly). Thus, the TT (otherwise of sufficiently good quality) of subject 8 , contained several rather long fragments that literally coincided with the MT TT. Their length amounted to 9, 10 (two fragments) and 15 words, which definitely proves the impact of the MT TT. The same is true about the TT of subject 15, where there is a considerable amount of literal coincidences (5-6 words long) with MT TT. In-between these fragments there might have been some words different from the MT TT, but then this pattern repeated again. This sandwich-like TT looks more like a post-edited MT TT than an original translation. 
Пост-редагування машинного перекладу як засіб активізаиії...

Table 3 shows the results of the subjects' performance analysis within cycle 2 -home tasks (weeks 4-6) and the interim test 2.

\section{Table 3}

The degrees of the students' post-editing intensity in their weekly home tasks 4-6 and their independence in the Interim test 2 (TN - task number, $\Sigma-$ sum total, IT - interim test, (-) - the task was not uploaded by the student)

\begin{tabular}{lcccccccccccccccccccccc}
\hline \multirow{2}{*}{ TN } & \multicolumn{1}{c|c}{} & 1 & 2 & 3 & 4 & 5 & 6 & 8 & 9 & 11 & 12 & 13 & 14 & 15 & 16 & 17 & 18 & 19 & 20 & 21 & 22 & 23 \\
\hline 4 & 10 & 6 & 1 & 10 & 7 & - & 10 & 9 & - & 10 & - & 9 & 10 & 7 & 10 & - & - & - & 10 & 9 & 10 \\
5 & 10 & - & 1 & 9 & 7 & - & 9 & 10 & 8 & 10 & 2 & - & 9 & 8 & 8 & - & 3 & - & 10 & 9 & 10 \\
6 & 10 & 7 & 1 & 10 & 8 & - & 10 & 9 & - & - & 1 & 10 & 9 & 8 & 10 & - & 1 & - & 10 & 7 & 10 \\
$\boldsymbol{\Sigma}$ & $\mathbf{3 0}$ & $\mathbf{1 3}$ & $\mathbf{1}$ & $\mathbf{2 9}$ & $\mathbf{2 2}$ & - & $\mathbf{2 9}$ & $\mathbf{2 8}$ & $\mathbf{8}$ & $\mathbf{2 0}$ & $\mathbf{3}$ & $\mathbf{1 9}$ & $\mathbf{2 8}$ & $\mathbf{2 3}$ & $\mathbf{2 8}$ & - & $\mathbf{4}$ & - & $\mathbf{3 0}$ & $\mathbf{2 5}$ & $\mathbf{3 0}$ \\
IT-2 & 10 & 3 & 2 & 8 & 6 & - & 7 & 10 & 4 & - & 4 & 7 & 8 & 7 & 8 & 7 & 3 & - & 10 & 7 & 9 \\
\hline
\end{tabular}

As it is clear from table 3 , in cycle 2 , if we discard the results of two subjects, who either did not participate in this cycle at all (subject 6) or did not write the Interim test 2 (subject 20), there is a general improvement of the subjects' performance. This upgrading concerns both the home task indicators (except subjects 12 and 19) and the Interim test 2, where the share of the subjects' results in the range of 7-10 points increased more than twofold $(61.0 \%$ against $30.0 \%$ in the Interim test 1). Only the results of subjects 2, 3, 13 and 19, though slightly higher, remained at a low level.

Having analysed the Interim test 2 results, we found a greater sophistication in some subjects' strategies to hide the use of MT in their TTs. The new element involved the transposition of the MT-generated TT fragments. For example, the MT TT of sentence 1 (One new research area is to examine the relation between intelligence and attention using a measure of attention derived from a classic procedure from cognitive psychology; in particular, a version of the selectiveattention procedure) may be subdivided into four fragments (A-D): 'Одним із нових напрямків досліджень (А) є вивчення зв'язку між інтелектом та увагою (В) за допомогою міри уваги, виведеної $з$ класичної процедури когнітивної психологї (C), зокрема, версія процедури вибіркової уваги (D)'. Subject 2 transposed these elements in the following way: 3 класичної прочедури когнітивної психологї (C), а зокрема з процедури вибіркової уваги (D), з'явилась нова галузь 
досліджень (A), що має на меті вивчення зв'язків між інтелектом та увагою (B).

In transposing the fragments of the imperfect MT-generated sentence, the combined effect of incomplete understanding of its content and its insufficient comparison with the ST resulted in semantic deviations (up to the use of antonymic expressions) and the preservation of identical fragments in different segments of the same sentence. For instance, the MT TT of sentence 5 (Therefore, we used, as a measure of the control of attention, the benefit for recall when a channel was monitored as opposed to not monitored in the dual-task situation) may be divided into six fragments: Тому ми використали (A) як міру контролю уваги (В) вигоду для відкликання (С), коли канал відстежувався (D), на відміну від відстежуваного (Е) в ситуації подвійного завдання (F). Subject 3 transposed these fragments without any substantial changes: Тому коли канал відстежувався (D), ми використовували (A) перевагу згадування (C), як вимір контролю уваги (В), коли канал спостерігався (D), на відміну від того, який відстежується (Е) в ситуації подвійного завдання (F). In fronting element D, she forgot to delete it in its former position, and thus it appears in this sentence twice - in the first and the fourth positions (see above). The fact that the subject relied on the MT TT is also proven by the fact that she retained in her TT the global error made by the machine - the computer translated the not monitored (channel) as (канал) який відстежується (monitored channel).

Table 4 shows the results of the subjects' performance analysis within cycle 3 - home tasks 7-11 and the Final test.

\section{Table 4}

The degrees of the students' post-editing intensity in their weekly home tasks 7-11 and their independence in the Final test (TN - task number, $\Sigma$ - sum total, FT - Final test, (-) - the work was not uploaded)

\begin{tabular}{lcccccccccccccccccccccc}
\hline \multirow{2}{*}{ TN } & 1 & 2 & 3 & 4 & 5 & 6 & 8 & 9 & 11 & 12 & 13 & 14 & 15 & 16 & 17 & 18 & 19 & 20 & 21 & 22 & 23 \\
\hline 7 & 9 & 8 & 1 & 10 & 7 & - & 9 & 10 & - & 10 & - & 10 & 10 & 8 & 10 & 8 & - & - & 10 & 7 & 10 \\
8 & 10 & 9 & 1 & 10 & 7 & - & 10 & 10 & - & 10 & - & 10 & 10 & 7 & 10 & - & 3 & - & 10 & 8 & 10 \\
9 & 10 & 9 & 1 & 10 & - & - & 10 & 10 & - & 10 & - & - & 9 & 8 & 10 & 8 & - & - & 10 & 8 & 10 \\
10 & 10 & 9 & 1 & 10 & - & - & 10 & 10 & - & 10 & - & - & 10 & 8 & 10 & 7 & 3 & - & 10 & 7 & 10 \\
11 & 10 & - & 1 & 10 & 7 & - & - & 10 & - & 10 & - & - & 9 & 7 & 10 & 7 & 3 & - & 10 & 7 & 10 \\
$\mathbf{\Sigma}$ & $\mathbf{4 9}$ & $\mathbf{3 5}$ & $\mathbf{5}$ & $\mathbf{5 0}$ & $\mathbf{2 1}$ & $\mathbf{0}$ & $\mathbf{3 9}$ & $\mathbf{5 0}$ & $\mathbf{0}$ & $\mathbf{5 0}$ & $\mathbf{0}$ & $\mathbf{2 0}$ & $\mathbf{4 8}$ & $\mathbf{3 8}$ & $\mathbf{5 0}$ & $\mathbf{3 0}$ & $\mathbf{9}$ & $\mathbf{0}$ & $\mathbf{5 0}$ & $\mathbf{3 7}$ & $\mathbf{5 0}$ \\
FT & 9 & 6 & 2 & 8 & 8 & 2 & 7 & 9 & 7 & 10 & 4 & 7 & 7 & 7 & 8 & 7 & 7 & 8 & 10 & 7 & 9 \\
\hline
\end{tabular}


As it follows from table 4, in cycle 3, there is some further improvement of both the home task (except subjects 6,11,13 and 20) and the Final test performance, where the share of the subjects' results in the range of $7-10$ points increased even more $(86.0 \%$ against $61.0 \%$ and $30.0 \%$ in the Interim tests 2 and 1 respectively). In the Final test, only the results of subjects 3, 6 and 13 remained at a low level, which correlates well with their low home task performance indicators as well. On the other hand, subject 20, who had not upload any home tasks within this cycle, achieved a high result ( 8 points) in her Final test.

Thus, we may assume a certain correlation between the amount of quality post-editing MT-generated TT during the subjects' homework and the degree of their independence (from the structure of the MT TT) in translating specialized texts. To establish the impact of the said amount on the general quality of the subjects' translation, we arbitrarily divided them into four groups (A-D) according to the degrees of their post-editing intensity in their weekly home tasks and their independence in the Interim and Final tests (the explanation of the meaning of levels A-D is provided above, before table 1). Table 5 shows the comparative data related to the said groups.

\section{Table 5}

Comparison of the subjects' parameters (in \%) by groups A-D

\begin{tabular}{lllll}
\hline Parameters & \multicolumn{4}{l}{ Groups of subjects } \\
\cline { 2 - 5 } & $\mathrm{A}$ & $\mathrm{B}$ & $\mathrm{C}$ & $\mathrm{D}$ \\
\hline Percentage of uploaded home tasks & 98.0 & 86.0 & 46.0 & 47.0 \\
Degree (in \%) of the subjects' post-editing intensity in their & 98.0 & 83.0 & 78.0 & 35.0 \\
weekly home tasks & & & & \\
The subjects' independence in the Interim and Final tests & 85.0 & 59.0 & 46.0 & 35.0 \\
Average mark in the Final test (out of 100) & 93.0 & 80.0 & 63.0 & 53.0 \\
\hline
\end{tabular}

As it can be seen in table 5, there are considerable differences between the groups by all parameters. The amount of home tasks uploaded by the subjects in groups $\mathrm{A}$ and $\mathrm{B}$ exceeds the similar parameter in groups $\mathrm{C}$ and D more than twofold (group A) and almost twofold (group B). Moreover, there is a considerable advantage of the groups A and B (and even C) subjects' post-editing intensity in their weekly home tasks as compared to group D $(98.0 \%, 83.0 \%$ and $78.0 \%$ in groups $\mathrm{A}, \mathrm{B}$ and $\mathrm{C}$ respectively against the mere $35.0 \%$ - in group $\mathrm{D})$. It generally means that throughout the semester, the intensity of analytical 
and thinking activity in the process of doing their home tasks was the highest one in group A $(98.0 \%)$, moderately high $(83.0 \%)$ - in group $\mathrm{B}$, average $(78.0 \%)$ - in group $\mathrm{C}$, and low $(35.0 \%)$ - in group $\mathrm{D}$, It is corroborated by the subjects' independence in the Interim and Final tests, the degree of which consistently decreases from $85.0 \%$ in group A до $59.0 \%, 46.0 \%$ and $35.0 \%$ in groups $\mathrm{B}, \mathrm{C}$ and $\mathrm{D}$ respectively. These tendencies correlate well with the performance of each group subjects in the Final test, where the average marks amounted to 93, 80, 63 i 53 points (out of 100) in groups A, B, C and D respectively.

\section{Conclusions}

Our pilot study was based on the hypothesis that the regular (weekly home tasks throughout a semester) post-editing of TT translated by means of the MT (Google Translate) system in combination with the TAP (Think-aloud protocol) procedure, modified for written translation, would contribute to the efficient development of specialized texts translation skills due to the promotion of students' analytical and thinking activity. The experimental results proved that an appropriate amount of the said post-editing reduced the students' dependence on the MT TT structure and correlated well with the quality of their independent (without MT) translation.

Our research also proved that special efforts are required to convince all the students of the necessity to do their post-editing tasks responsibly in order to provide for the proper amount and intensity of their analytical and thinking activity, and to prevent the students' formalistic approach to post-editing (sporadic substitution of some words in the MT TT with their synonyms, mechanic transposition of the MT TT sentence fragments, lack of proper argumentation of the MT TT corrections made by the student, etc.). The formalistic approach deprives post-editing of its teaching effect as, in this case, a proper intensity of the students' analytical and thinking activity is not achieved, and its potential positive impact upon the development of the students' competence of translating specialized texts is substantially diminished.

To test the preliminary conclusions suggested in this paper, the experiment ought to be replicated in another educational context on a different material and involving a larger sample of subjects. In our 
experiment, the subjects were compared with each other, and we also contrastively assessed the indicators of arbitrary groups (A, B, C and D). However, the prospective future research should use the control and experimental groups instead, to improve the reliability of conclusions. This assumption requires additional verification, which is the prospect of our further investigation.

\section{References}

Alonso, E., \& Calvo, E. (2015). Developing a Blueprint for a Technologymediated Approach to Translation Studies. Meta, 60(1), 135-157. https://doi. org/10.7202/1032403ar

Burchardt, A., Lommel, A., Bywood, L., Harris, K., \& Popović, M. (2016). Machine translation quality in an audiovisual context. Target, 28(2), 206-221. https://doi. org/10.1075/target.28.2.03bur

CEFR: The Common European Framework of Reference for Languages: Learning, Teaching, Assessment. Companion volume with new descriptors. (2018). Cambridge : Cambridge University Press.

Chernovaty, L. (2021). Post-editing as the means to activate students' thinking and analytical process: Psycholinguistic aspects. Available at SSRN: https://ssrn.com/ abstract $=3955160$

Cifuentes-Ferez, P., \& Rojo, A. (2015). Thinking for Translating. Think-aloud Protocol on the translation of manner-of-motion verbs. Target, 27(2), 273-300. https://doi. org/10.1075/target.27.2.05cif

Daems, J., Vandepitte, S., Hartsuiker, R.J., \& Macken, L. (2017). Translation Methods and Experience: A Comparative Analysis of Human Translation and Post-editing with Students and Professional Translators. Meta, 62(2), 245-270. https://doi. org/10.7202/1041023ar

Esqueda, M.D. (2021). Machine translation: teaching and learning issues. Trabalhos em Linguística Aplicada, 60(1), 282-299. https://doi.org/10.1590/0103181393200 1520210212

Gaspari, F., Almaghout, H., \& Doherty, S. (2015). A survey of machine translation competences: Insights for translation technology educators and practitioners. Perspectives, 23(3), 333-358. https://doi.org/10.1080/0907676X.2014.979842

ISO 171000. (2015). International Standard in Translation Services - Requirements for Translation Services. Retrieved from https://www.iso.org/standard/59149.html

Kenny, D., \& Doherty, S. (2014). Statistical machine translation in the translation curriculum: overcoming obstacles and empowering translators. The Interpreter and Translator Trainer, 8(2), 276-294. https://doi.org/10.1080/1750399X.2014.936112

Loock, R. (2018). Traduction automatique et usage linguistique: une analyse de traductions anglais-français réunies en corpus. Meta, 63(3), 786-806. https://doi. org/10.7202/1060173ar

Man, D., Mo, A., Chau, M.H., O’Toole, J.M., \& Lee, Ch. (2020). Translation technology adoption: evidence from a postgraduate programme for student translators in China. Perspectives, 28(2), 253-270. https://doi.org/10.1080/09076 76X.2019.1677730 
Mellinger, Ch.D. (2018). Re-thinking translation quality. Revision in the digital age. Target, 30(2), 310-331. https://doi.org/10.1075/target.16104.mel

Mellinger, Ch.D. (2017). Translators and machine translation: knowledge and skills gaps in translator pedagogy. The Interpreter and Translator Trainer, 11(4), 280 293. https://doi.org/10.1080/1750399X.2017.1359760

Moorkens, J. (2018). What to expect from Neural Machine Translation: a practical in-class translation evaluation exercise. The Interpreter and Translator Trainer, 12(4), 375-387. https://doi.org/10.1080/1750399X.2018.1501639

O'Brien, Sh., \& Rossetti, A. (2020). Neural machine translation and the evolution of the localisation sector. The Journal of Internationalization and Localization, 7(12), 95-121. https://doi.org/10.1075/jial.20005.obr

Pym, A. (2013). Translation Skill-Sets in a Machine-Translation Age. Meta, 58(3), 487-503. https://doi.org/10.7202/1025047ar

Rodríguez de Céspedes, B. (2019). Translator Education at a Crossroads: the Impact of Automation. Lebende Sprachen, 64(1), 103-121. https://doi.org/10.1515/les2019-0005

Sang-Bin, L. 이상빈. (2018). Gugnaehagbu beon-yeogjeongongjaui gugeul gigyebeonyeog poseuteuediting gwajeong(process) mich haeng-wi yeongu. 국내학부 번역전공자의 구글 기계번역 포스트에디팅 과정(process) 및 행위 연구. [Process research into post-editing: How do undergraduate students post-edit the output of Google Translate?]. 번역학연구 - The Journal of Translation Studies, 19(3), 259-286. https://doi.org/10.15749/jts.2018.19.3.010 [in Chinese].

Schmidhofer, A., \& Mair, N. (2019). La traducción automática en la formación de traductores. CLINA: Revista Interdisciplinaria de Traducción, Interpretación y Comunicación Intercultural, 4(2), 163-180. https://doi.org/10.14201/ clina201842163180

Underwood, N.L., \& Jongejun, B. (2001). Translatability Checker: A Tool to Help Decide Whether to Use MT. In B. Maegaard (Ed.), Proceedings of MT Summit VIII: Machine Translation in the Information Age (Galicia, September 18-22, 2001) (pp. 363-368). Santiago de Compostela.

Yang, Y., Wang, X., \& Yuan, Q. (2021). Measuring the usability of machine translation in the classroom context. Translation and Interpreting Studies, 16(1), 101-123. https://doi.org/10.1075/tis.18047.yan

\section{АНОТАЦІЯ}

Метою статmі $\epsilon$ вивчення шляхів активізації мисленнєво-аналітичної діяльності майбутніх перекладачів під час самостійної роботи в дистанційному навчанні. Автор сподівається досягти цього шляхом поєднання постредагування машинного перекладу та методики "Міркуй вголос" (Thinkaloud protocol). Припускається, що таке поєднання також зменшує залежність студентів від впливу структури тексту, створеного машиною, та підвищує ефективність перекладу спеціалізованих текстів.

Методологія дослідження включала проведення експериментального онлайнового навчання (28 аудиторних годин та 92 години самостійної роботи) із застосуванням пост-редагування студентів першого курсу магістратури (спеціалізація “Переклад"), рівень володіння англійською мовою яких коливалася 
між рівнями С1 та С2, перекладу українською мовою англомовних текстів у сфрері психології. Параметри аналізу виконання завдань на пост-редагування включали відсоток виконаних завдань, ступінь неформальності постредагування, ступінь самостійності під час виконання контрольних робіт та оцінка підсумкової контрольної роботи.

Результати аналізу засвідчили, що спостерігається суттєва відмінність між різними групами випробуваних за всіма параметрами. Обсяг виконаних домашніх завдань в групах А і В (з вищою активністю мисленнєво-аналітичної діяльності) вдвічі перевищує аналогічний показник в групах C активністю). Значна перевага груп $A$ і B (і навіть C) спостерігається також в ступені неформальності пост-редагування. Тобто інтенсивність мисленнєвоаналітичної діяльності під час виконання домашніх завдань випробуваних групи А була найвищою, групи В - помірно високою, групи C - середньою, $а$ групи $D$ - низькою. Ступінь самостійності під час виконання контрольних робіт знижується від 85.\% в групі $A$ до $35.0 \%$ в групі D, результати інших груп знаходяться між ними - 59.0\% (група В) та 46.0\% (група С). Згадані тенденції чітко корелюють і з середніми оцінками підсумкової контрольної роботи, які склали 93, 80, 63 і 53 (з максимально можливих 100) бали в групах A, B, C і D відповідно.

Висновки. Пост-редагування (у поєднанні з модифікованою методикою "Міркуй вголос") сприяє ерективнішому розвитку вміння перекладати спеціалізовані тексти за рахунок активізації мисленнєво-аналітичної діяльності студентів, зменшує залежність студентів від впливу МП та корелює з підвищенням загальної якості їхнього перекладу.

Ключові слова: машинний переклад, методика "Міркуй вголос", мисленнєвоаналітична діяльність, онлайнове навчання, письмовий переклад, постредагування, психологія, спеціалізований переклад.

\section{Черноватый Леонид \& Ковальчук Наталья. Пост-редактирование машинного} перевода как средство активизации мыслительно-аналитической деятельности студентов: психолингвистический аспект

\section{АННОТАЦИЯ}

Целью работы является изучение способов активизации мыслительноаналитической деятельности будущих переводчиков во время самостоятельной работы в дистанционном обучении. Автор надеется достичь этого путем сочетания машинного перевода и методики "Рассуждай вслух" (Thinkaloud protocol). Предполагается, что такое сочетание также уменьшает зависимость студентов от влияния структуры текста, созданного машиной, и повышает эфрективность перевода специализированных текстов.

Методология исследования включала проведение экспериментального онлайн-обучения (28 аудиторных часов и 92 часа самостоятельной работы) с применением постредактирования студентов первого курса магистратуры 
(специализация “Перевод"), уровень владения английским языком которых колебался между уровнями C1 и C2 по классификации CEFR, переводу на украинский язык англоязычных текстов в области психологии. Параметры анализа выполнения задач на постредактирование включали процент выполненных заданий, степень неформальности постредактирования, степень самостоятельности при выполнении контрольных работ и оценка итоговой контрольной работы. Результаты анализа показали, что наблюдается существенное отличие между разными группами испытуемых по всем параметрам. Объем выполненных домашних заданий в группах $A$ и $B$ (с более высоким уровнем активности мыслительно-аналитической деятельности) вдвое превышает аналогичный показатель в группах C и D (с более низкой активностью). Значительное преимущество групп $A$ u $B$ (и даже C) наблюдается также в степени неформальности постредактирования. То есть интенсивность мыслительно-аналитической деятельности при выполнении домашних заданий испытуемых группы А была высокой, группы В - умеренно высокой, группы C - средней, а группы D - низкой. Степень самостоятельности при выполнении контрольных работ снижается от 85.0\% в группе А до $35.0 \%$ в группе $D$, а результаты других групп находятся между ними - 59.0\% (группа B) и 46.0\% (группа С). Упомянутые тенденции четко коррелируют и со средними оценками итоговой контрольной работы, которые составили 93, 80, 63 и 53 баллов (из максимально возможных 100) в группах $A, B, C$ и D соответственно. Выводы. Постредактирование (в сочетании с модифицированной методикой "Рассуждай вслух") способствует более эффрективному развитию умения переводить специализированные тексты за счет активизации мыслительноаналитической деятельности студентов, уменьшает зависимость студентов от влияния МП и коррелирует с повышением общего качества их перевода.

Ключевые слова: машинный перевод, методика "Рассуждай вслух", мыслительно-аналитическая деятельность, онлайн-обучение, письменный перевод, постредактирование, психология, специализированный перевод. 